Tropical Journal of Pharmaceutical Research May 2020; 19 (5): 1081-1086

ISSN: $1596-5996$ (print); 1596-9827 (electronic) (C) Pharmacotherapy Group, Faculty of Pharmacy, University of Benin, Benin City, 300001 Nigeria

\title{
Bergenin from Cissus javana DC. (Vitaceae) root extract enhances glucose uptake by rat L6 myotubes
}

\author{
Htoo Tint San ${ }^{1,2}$, Panitch Boonsnongcheep ${ }^{3}$, Waraporn Putalun ${ }^{3}$, Boonchoo \\ Sritularak ${ }^{1}$, Kittisak Likhitwitayawuid ${ }^{1 *}$ \\ ${ }^{1}$ Department of Pharmacognosy and Pharmaceutical Botany, Faculty of Pharmaceutical Sciences, Chulalongkorn University, \\ Bangkok 10330, Thailand, ' ${ }^{2}$ Department of Pharmacognosy, University of Pharmacy (Yangon) 11031, Myanmar, ${ }^{3}$ Faculty of \\ Pharmaceutical Sciences, Khon Kaen University, Khon Kaen 40002, Thailand
}

*For correspondence: Email: Kittisak.L@chula.ac.th; Tel: +66 2188360

Sent for review: 18 January 2020

Revised accepted: 24 April 2020

\begin{abstract}
Purpose: To examine the glucose uptake stimulatory activity of the root extract of Cissus javana DC. (Vitaceae) in L6 myotubes of rat, and also to identify the extract's active principles.

Methods: The methanol extract was prepared from Cissus javana tuberous roots and evaluated for glucose uptake stimulatory effects on L6 rat muscle cells and inhibitory activity against a-glucosidase. The chemical components were isolated using several chromatographic techniques, and their structures characterized by spectroscopic methods. Each isolate was then assayed for glucose uptake stimulatory and $\alpha$-glucosidase inhibitory activities.

Results: The extract $(100 \mu \mathrm{g} / \mathrm{ml})$ exhibited glucose uptake stimulatory effect $(70.9 \%$ enhancement) and $\alpha$-glucosidase enzyme inhibitory activity (100\% inhibition). Through chromatographic separation, bergenin, stigmast-4-en-3-one and $\beta$-sitosterol were isolated and identified. Bergenin, at $100 \mu \mathrm{g} / \mathrm{ml}$ (0.3046 mM), increased glucose uptake by L6 myotubes by $50.5 \%$ without toxicity. At the same concentration, bergenin showed no inhibition on a-glucosidase enzyme, while stigmast-4-en-3-one and $\beta$-sitosterol exhibited 98.6 and $40.6 \%$, inhibition, respectively.

Conclusion: This study is the first report on the chemical constituents, and the glucose uptake stimulatory and $\alpha$-glucosidase inhibitory activities of Cissus javana DC. roots. The findings reveal the antidiabetic potential of the plant and the glucose-uptake enhancing activity of bergenin.
\end{abstract}

Keywords: Cissus javana, a-Glucosidase, Antidiabetes, Rat skeletal muscle cells, Bergenin

\begin{abstract}
This is an Open Access article that uses a fund-ing model which does not charge readers or their institutions for access and distributed under the terms of the Creative Commons Attribution License (http://creativecommons.org/licenses/by/4.0) and the Budapest Open Access Initiative (http://www.budapestopenaccessinitiative.org/read), which permit unrestricted use, distribution, and reproduction in any medium, provided the original work is properly credited.

Tropical Journal of Pharmaceutical Research is indexed by Science Citation Index (SciSearch), Scopus, International Pharmaceutical Abstract, Chemical Abstracts, Embase, Index Copernicus, EBSCO, African Index Medicus, JournalSeek, Journal Citation Reports/Science Edition, Directory of Open Access Journals (DOAJ), African Journal Online, Bioline International, Open-J-Gate and Pharmacy Abstracts
\end{abstract}

\section{INTRODUCTION}

Diabetes mellitus (DM) is a chronic disease characterized by elevated blood glucose level. Severe complications associated with DM, such as cardiovascular disease and damage to nerves, eyes and kidneys, frequently occur and often lead to premature death [1]. Currently, several classes of oral antidiabetic agents are available. Biguanides, such as metformin, are anti-DM drugs that act by stimulating glucose uptake by muscle cells and reducing insulin resistance. However, the long-term use of these drugs can lead to vitamin $\mathrm{B}_{12}$ and folic acid 
deficiency, lactic acidosis and renal insufficiency [2]. In recent years, glucose-uptake enhancers of plant origin have been the subject of interest $[3,4]$.

The genus Cissus (Vitaceae), also known as Vitis, consists of 350 species, widely distributed in China, India, Bangladesh, Nepal, and Southeast Asia [5]. Several species of Cissus, including C. cornifolia, C. barbeyana, C. repens, $C$. vinifera and $C$. verticillata, have been reported for antidiabetic potential [6-10].

Cissus javana DC. has several synonyms, including Vitis discolor (Blume) Dalzell, Cissus discolor Blume, Cissus javana var. pubescens $\mathrm{C}$. L. Li, and Cissus sicyoides Klein ex Steud. [11]. The plant is an herbaceous climber with distinct leaves (Figure 1). The upper surface contains white patches, whereas the lower surface is purple. Leaves are mostly ovate shaped with a heart-shaped base and an apiculate apex [12]. In Myanmar, the tuberous roots are used as a folk medicine for treating ovarian cancer [13], while in India, the leaves are known for anti-DM activity [14]. Prior to the present work, no studies on the anticancer or anti-DM constituents of $C$. javana roots have been described.
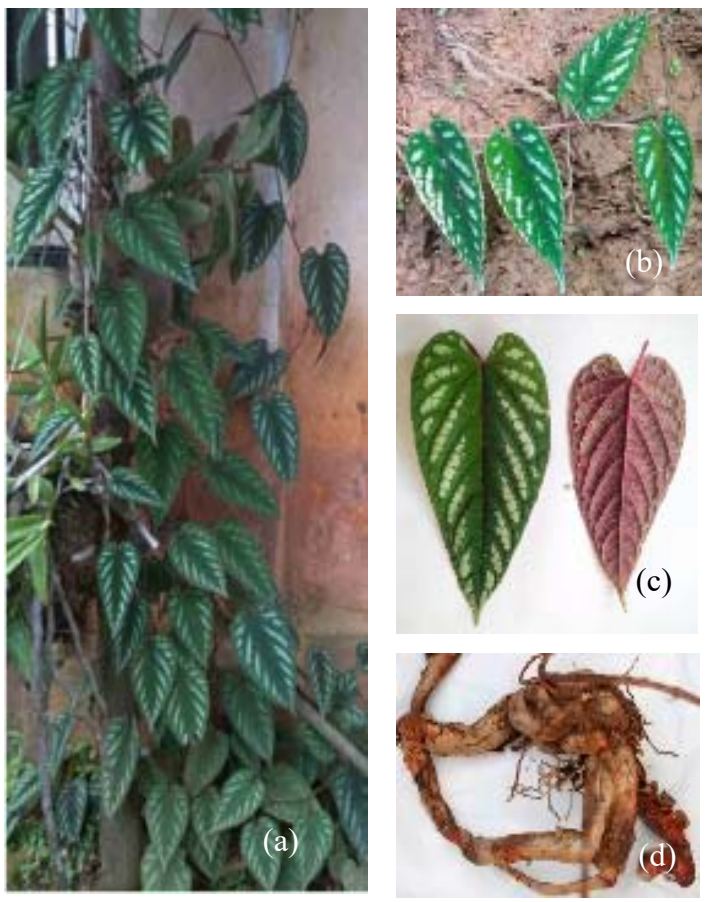

Figure 1: Cissus javana: (a) whole plant; (b) branch; (c) leaves; (d) tuberous roots

In this investigation, the $\mathrm{MeOH}$ extract, and fractions $A$ and $B$ (prepared from the roots of Cissus javana; see the experimental) were screened for cytotoxicity against human cancer cells, but none of them showed activity $\left(\mathrm{IC}_{50}>50\right.$ $\mu \mathrm{g} / \mathrm{ml}$; data not shown). However, the $\mathrm{MeOH}$ extract, when tested at $100 \mu \mathrm{g} / \mathrm{ml}$, exhibited 70 $\%$ stimulation of glucose uptake by $\mathrm{L} 6$ rat skeletal muscle cells and $100 \%$ inhibition of $\alpha$ glucosidase enzyme. These results prompted us to further our study to identify the constituents responsible for the anti-DM potential of this plant.

\section{EXPERIMENTAL}

\section{General}

Mass spectra were obtained on a Bruker micro TOF mass spectrometer. NMR experiments were conducted using a Bruker Avance DPX-300 NMR spectrometer. Column chromatography was performed on silica gel (Merck). Gel filtration was carried out on Sephadex LH-20 (GE Healthcare). A Biochom EZ Read 400 microplate reader was used to measure the absorbance of samples in microtiter plates.

\section{Plant materials}

Cissus javana DC. roots were collected from Shan State, Myanmar in July 2017. The plant was authenticated by comparison with herbarium specimens at University of Pharmacy, Yangon, Myanmar.

\section{Chemicals}

Fetal bovine serum (FBS), alpha minimal essential medium ( $\alpha-M E M)$, and penicillinstreptomycin $(10000 \mathrm{IU} / \mathrm{ml})$ were obtained from Thermo Fisher Scientific (Grand Island, NY, USA). Acarbose, glucose oxidase (GO) assay kit, a-glucosidase (from Saccharomyces cerevisiae), 3-(4,5-dimethyl thiazol-2-yl)-5-diphenyl tetrazolium bromide (MTT), p-nitrophenyl-Dglucopyranoside ( $p N P G)$ and sodium dodecyl sulfate (SDS) were purchased from Sigma Aldrich (St. Louis, MO, USA). Insulin (100 IU/ml) was from Biocon (Bangalore, India).

\section{Cell lines and culture media}

L6 cell culture (Rat skeletal muscle, ATCC ${ }^{\circledR} \mathrm{CRL}$ 1458) was purchased from the American Type Culture Collection (Manassas, VA, USA). The cells were cultured in growth medium (a-MEM with $10 \%$ FBS and $1 \%$ penicillin-streptomycin) and maintained at $37^{\circ} \mathrm{C}$ under $5 \% \mathrm{CO}_{2}$ atmosphere.

\section{Extraction and isolation}

The dried powder of tuberous roots of Cissus javana DC. $(190 \mathrm{~g})$ were macerated with $\mathrm{MeOH}$ ) 
$(1 \mathrm{~L} \times 3)$. The dried $\mathrm{MeOH}$ extract $(8.8 \mathrm{~g})$ was then treated with EtOAc to give EtOAc insoluble (fraction $A, 6.36 \mathrm{~g}$ ) and soluble (fraction $B, 2.38$ g) fractions after drying. Fraction $A$ was separated by vacuum liquid chromatography (silica gel, hexane-EtOAc-MeOH) to give five fractions (Al to AV). Compound 1 (245 mg) was collected as colorless crystals from fraction All after drying.

Fraction B was further separated on a silica gel column (hexane-EtOAc) to seven subfractions (BI to BVII). BII was further fractioned on Sephadex $\mathrm{LH}-20\left(\mathrm{CH}_{2} \mathrm{Cl}_{2}\right)$ to give fifteen fractions (BII1-Bll15). Purification of Bll5 on a Sephadex $\mathrm{LH}-20(\mathrm{MeOH})$ column yielded compound 2 (12 $\mathrm{mg}$ ). BIV gave white precipitates upon standing at room temperature overnight. The precipitates were collected, washed with EtOAc and dried to give compound 3 (50 mg). Compound 2 (12 mg) was also obtained from fraction BVI as colorless crystals after evaporation of the solvent.

\section{Assay for cytotoxicity against cancer cells}

Assays for cytotoxic activity against human breast cancer (MDA-MB-231) cells were kindly carried out by $\mathrm{Dr} P$ Rojsitthisak, using established protocols [15].

\section{$\alpha$-glucosidase inhibition assay}

The $\alpha$-glucosidase inhibition assay was carried out following previously reported protocols [3,4]. The inhibitory activity of each test compound was based on the ability to reduce the release of $p$ nitrophenol from the substrate pNPG, in comparison with the positive control acarbose.

\section{Glucose uptake stimulation assay}

The glucose uptake stimulation assay was performed on L6 skeletal muscle cells according to reported methods $[3,4]$. Positive controls were metformin and insulin.

\section{Cytotoxicity against 16 cells}

Cytotoxicity of each test compound is evaluated by the MTT [3-(4,5-dimethyl thiazol-2-yl)-5diphenyl tetrazolium bromide] assay method $[3,4]$.

\section{Statistical analysis}

The data are presented as mean $\pm S D$, and were analyzed by analysis of variance (ANOVS) using GraphPad, version 7.00 for Windows. $P<0.05$ ) was considered statistically significant.

\section{RESULTS}

The $\mathrm{MeOH}$ extract and fractions $\mathrm{A}$ and $\mathrm{B}$ were evaluated for toxicity against $\mathrm{L} 6$ cells and glucose-uptake stimulatory activity at 1, 10 and $100 \mu \mathrm{g} / \mathrm{ml}$. None of them showed cytotoxicity (cell viability $>80 \%$ ) (Figure 2 ).

The $\mathrm{MeOH}$ extract at 10 and $100 \mu \mathrm{g} / \mathrm{ml}$ could stimulate glucose uptake by 41.8 and $70.9 \%$, respectively. Fraction $A$ appeared to have stronger activity, with 52.0, 72.4 and $75.3 \%$ enhancement at 1,10 and $100 \mu \mathrm{g} / \mathrm{ml}$, respectively, but fraction $B$ displayed much less activity, showing stimulatory activity only at 100 $\mu \mathrm{g} / \mathrm{ml}(57.8 \%$ ) (Figure 2 and Table 1).

Table 1: Glucose uptake stimulatory activity of Cissus javana

\begin{tabular}{|c|c|c|}
\hline Sample & $\begin{array}{c}\text { Glucose } \\
\text { uptake (\%) }\end{array}$ & Enhancement (\%) \\
\hline DMSO & 100 & 0 \\
\hline $\begin{array}{l}\text { Metformin (2 } \\
\mathrm{mM})\end{array}$ & $218.9 \pm 4.4^{*}$ & $118.9 \pm 3.6$ \\
\hline $\begin{array}{l}\text { Insulin (500 } \\
\text { nM) }\end{array}$ & $192.7 \pm 13.1^{*}$ & $92.7 \pm 10.7$ \\
\hline \multicolumn{3}{|l|}{ MeOH extract } \\
\hline $1 \mu \mathrm{g} / \mathrm{ml}$ & $102.5 \pm 25.6$ & NA \\
\hline $10 \mu \mathrm{g} / \mathrm{ml}$ & $141.8 \pm 35.3^{*}$ & $41.8 \pm 28.8$ \\
\hline $100 \mu \mathrm{g} / \mathrm{ml}$ & $170.9 \pm 15.1^{*}$ & $70.9 \pm 12.3$ \\
\hline \multicolumn{3}{|l|}{ Fraction $A$} \\
\hline $1 \mu \mathrm{g} / \mathrm{ml}$ & $152.0 \pm 10.9^{*}$ & $52.0 \pm 9.0$ \\
\hline $10 \mu \mathrm{g} / \mathrm{ml}$ & $172.4 \pm 12.6^{*}$ & $72.4 \pm 10.3$ \\
\hline $100 \mu \mathrm{g} / \mathrm{ml}$ & $175.3 \pm 23.1^{*}$ & $75.3 \pm 18.9$ \\
\hline \multicolumn{3}{|l|}{ Fraction $B$} \\
\hline $1 \mu \mathrm{g} / \mathrm{ml}$ & $82.2 \pm 11.0$ & NA \\
\hline $10 \mu \mathrm{g} / \mathrm{ml}$ & $114.2 \pm 24.3$ & NA \\
\hline $100 \mu \mathrm{g} / \mathrm{ml}$ & $157.8 \pm 24.3^{*}$ & $57.8 \pm 19.8$ \\
\hline \multicolumn{3}{|l|}{ Bergenin } \\
\hline $\begin{array}{l}1 \mu \mathrm{g} / \mathrm{ml} \\
(0.003 \mathrm{mM})\end{array}$ & $79.3 \pm 19.0$ & NA \\
\hline $\begin{array}{l}(0.0304 \\
\mathrm{mM})\end{array}$ & $124.3 \pm 36.3$ & NA \\
\hline $\begin{array}{l}100 \mu \mathrm{g} / \mathrm{ml} \\
(0.304 \mathrm{mM})\end{array}$ & $150.5 \pm 9.1^{*}$ & $50.5 \pm 7.4$ \\
\hline
\end{tabular}

${ }^{*} P<0.05$; significantly different when compared to the control (DMSO); NA = not applicable

Chromatographic separation of fractions $A$ and $B$ gave compounds 1, 2 and 3 (Figure 3). They were identified as bergenin [16], stigmast-4-en-3one [17], and $\beta$-sitosterol [18], respectively, based on their NMR and MS spectral data. 

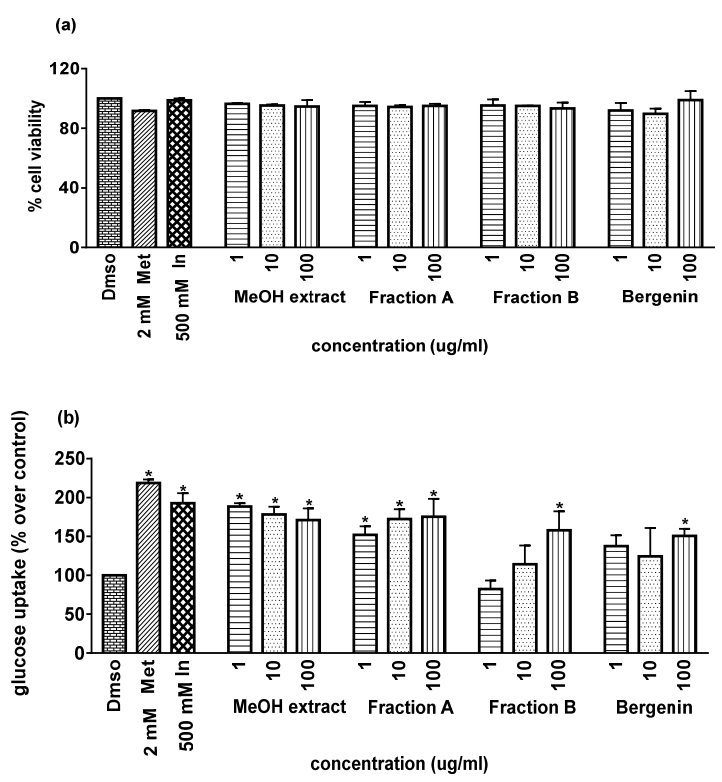

Figure 2: Cytotoxicity (a) and glucose uptake stimulation (b) of $\mathrm{MeOH}$ extract, fractions and bergenin; ${ }^{*}(p<0.05)$ Significantly different when compared to the control (DMSO). DMSO (control); Met $=$ metformin, In = insulin (positive control)

\section{DISCUSSION}

Bergenin (1) has been previously isolated from several species of Cissus [19-20]. Compound 2 has been earlier found in Cissus repens [7], whereas 3 has been reported from $C$. polyantha [21]. Compounds $\mathbf{1}$ - $\mathbf{3}$ were subjected to assays for glucose uptake stimulatory potential. Unfortunately, the results for 2 and $\mathbf{3}$ could not be obtained because of their poor solubility in the test system, and this may partly account for the low activity of fraction $B$.

Bergenin (1) did not show activity at the concentrations of 1 and $10 \mu \mathrm{g} / \mathrm{ml}$ but enhanced the glucose uptake by $50.5 \%$ at $100 \mu \mathrm{g} / \mathrm{ml}$ $(0.3046 \mathrm{mM})$. This result was quite impressive when compared with the percent enhancement by insulin $(92.7 \%$ at $500 \mathrm{nM})$ or metformin $(118.9 \%$ at $2 \mathrm{mM})$ (Figure 2). Interestingly, Kumar et al. investigated the hypoglycemic action of bergenin using streptozotocinnicotinamide-induced type-2 diabetic rats and found that the compound could reduce the fasting blood glucose level in rats without effects on liver glycogen [22]. The findings in our study may suggest the mechanism of action of bergenin although more detailed studies are still needed. It should also be noted that 1 can be considered as structurally related to hydrolyzable tannins. Earlier studies revealed that the tannins present in plants could stimulate glucose uptake and inhibit adipogenesis [23].

In the assays for in-vitro $\alpha$-glucosidase inhibitory activity, bergenin (1) showed no activity $(2.2 \%$ inhibition at $100 \mu \mathrm{g} / \mathrm{ml}$ ), which was in agreement with a previous report [24]. The phytosterols 2 and $\mathbf{3}$ exhibited significant inhibitory effects (98.6 $\%$ and $40.6 \%$ inhibition, respectively) in comparison with acarbose (21.9\% inhibition). These findings were consistent with earlier reported values [25].

\section{CONCLUSION}

The findings of this study indicate that a $\mathrm{MeOH}$ extract prepared from the tuberous roots of Cissus javana showed glucose uptake stimulatory activity and a-glucosidase inhibitory effect. Separation of the extract led to the isolation of 3 compounds, namely bergenin (1), stigmast-4-en-3-one (2) and $\beta$-sitosterol (3). Bergenin (1) displayed remarkable glucoseuptake stimulatory activity on L6 rat skeletal muscle cells, but no a-glucosidase inhibitory potential. Steroids $\mathbf{2}$ and $\mathbf{3}$ showed recognizable a-glucosidase effects. However, they were not examined for the ability to enhance glucose uptake due to their poor solubility in the test<smiles>COc1c(O)cc2c(c1O)C1O[C@H](CO)[C@@H](O)C(O)[C@H]1OC2=O</smiles>

(1)

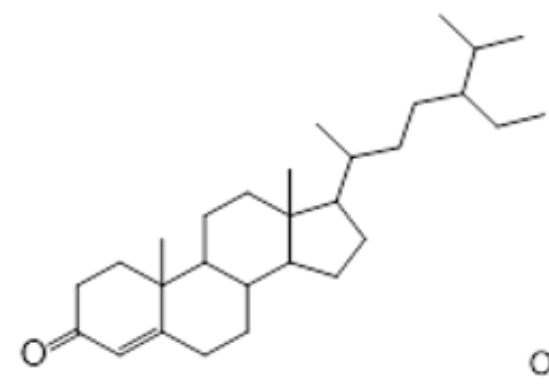

(2)

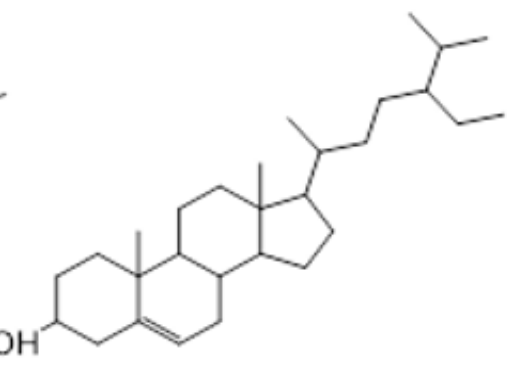

(3)

Figure 3: Structures of bergenin (1), stigmast-4-en-3-one (2) and $\beta$-sitosterol (3) 
system. These results suggest that the tuberous roots of Cissus javana DC. could be a potential source for the development of new antidiabetic drugs. To the best of our knowledge, this study is the first report of the chemical constituents and antidiabetic potential of the roots of Cissus javana.

\section{DECLARATIONS}

\section{Acknowledgement}

HTS is grateful for a PhD scholarship from the Graduate School of Chulalongkorn University. We thank Dr Pornchai Rojsitthisak for the assays for cytotoxicity against cancer cells.

\section{Conflicts of interest}

No conflicts of interest associated with this work.

\section{Contribution of authors}

The authors declare that this work was done by the authors named in this article and all liabilities pertaining to claims relating to the content of this article will be borne by them. HTS was responsible for the plant collection, isolation of compounds and a-glucosidase inhibition assays, as well as the preparation of the manuscript. PB and WP contributed to the cell-based assays for L6 glucose uptake and cytotoxicity. $\mathrm{KL}$ and BS supervised the project, reviewed the results and did critical reading and editing of the manuscript. All the authors have read the final manuscript and approved the submission.

\section{Open Access}

This is an Open Access article that uses a funding model which does not charge readers or their institutions for access and distributed under the terms of the Creative Commons Attribution License (http://creativecommons.org/licenses/by/ 4.0) and the Budapest Open Access Initiative (http://www.budapestopenaccessinitiative.org/rea d), which permit unrestricted use, distribution, and reproduction in any medium, provided the original work is properly credited.

\section{REFERENCES}

1. World Health Organization. Guidelines on second- and third-line medicines and type of insulin for the control of blood glucose levels in non-pregnant adults with diabetes mellitus. World Health Organization. 2008 [cited 2019 Sep 20]. Available from: https://apps.who. int/iris/handle/10665/272433.
2. Chaudhury A, Duvoor $C$, Dendi $R$, Sena V, Kraleti $S$, Chada A, Ravilla R, Marco A, Shekhawat NS, Montales $M T$ et al. Clinical review of antidiabetic drugs: implications for type 2 diabetes mellitus management. Front Endocrinol (Lausanne) 2017; 8: 6.

3. Inthongkaew $P$, Chatsumpun $N$, Supasuteekul $C$, Kitisripanya $T$, Putalun W, Likhitwitayawuid $K$, et al. $\alpha$ Glucosidase and pancreatic lipase inhibitory activities and glucose uptake stimulatory effect of phenolic compounds from Dendrobium formosum. Rev Bras Farmacogn 2017; 27(4): 480-487.

4. San HT, Boonsnongcheep $P$, Putalun $W$, Mekboonsonglarp W, Sritularak B, Likhitwitayawuid $K$. $\alpha$-Glucosidase inhibitory and glucose uptake stimulatory effects of phenolic compounds from Dendrobium christyanum. Nat Prod Comm 2020; 15(3): 1-8, DOI: 10.1177/1934578X20913453.

5. Fatma N. Phtytogeographical distribution of Indian Vitaceae: a report. Int J Sci Res 2016; 5(3); 2113-2117.

6. Suresh K, Sunil S. Anti-diabetic potential of Vitis vinifera root extract against streptozotocin induced diabetic rats. Int J Res Med Sci 2010; 3(1/2): 19-23.

7. Nyunt KS, Elkhateeb A, Tosa Y, Nabata K, Katakura K, Matsuura $H$. Isolation of antitrypanosomal compounds from Vitis repens, a medicinal plant of Myanmar. Nat Prod Commun 2012; 7(5): 609-610.

8. Jimoh A, Tanko Y, Mohammed A. Modulatory role of methanolic leaf extract of Cissus cornifolia on blood glucose levels of normoglycemic wistar rats. Euro J Exp Bi 2013; 3(1): 22-27.

9. Obidike I, Salawu O. Inhibitory effects of Cissus barbeyana leaf extracts on $\alpha$-amylase and $\alpha$ glucosidase in vitro. Planta Med 2010; 76(12): 679.

10. Lino CS, Sales TP, Gomes PB, Amaral JF, Alexandre FS, Silveira ER, Ferreira JM, de Sousa DF, de Queiroz $M G$, de Sousa FC et al. Anti-diabetic activity of a fraction from Cissus verticillata and tyramine, its main bioactive constituent, in alloxan-induced diabetic rats. Am J Pharmacol Toxicol 2007; 2(4): 178-188.

11. The Plant List. Version 1. [Published on the Internet] [cited 2019 Sep 20]. Available from: http://www.theplantlist.org/

12. eFloras. [Published on the Internet]. Missouri Botanical Garden, St. Louis, MO \& Harvard University Herbaria, Cambridge, MA [cited 2019 Sep 20]. Available from: http://www.efloras.org/

13. Myint, KW. Survey on the Lesser Known Species of Medicinal Plants of East Yoma and the Socio-Economic Status of the Local Communities. Forest Research Institute, Forest Department, Ministry of Forestry, Myanmar; 2000. 15-17p.

14. Ali A, Manikandan S, Lakshmanan GM. Review on Phytochemical and Pharmacological activities of the genus Cissus Linn. J Pharm Res Int 2017; 8(4): 1-7.

15. Bhunchu S, Muangnoi C, Rojsitthisak $P$, Rojsitthisak $P$. Curcumin diethyl disuccinate encapsulated in chitosan/alginate nanoparticles for improvement of its in 
vitro cytotoxicity against MDA-MB-231 human breast cancer cells. Pharmazie 2016; 71(12): 691-700.

16. De Abreu HA, Lago IA, Souza GP, Piló-Veloso D, Duarte $H A$, Alcântara AF. Antioxidant activity of (+)-bergenin-a phytoconstituent isolated from the bark of Sacoglottis uchi Huber (Humireaceae). Org Biomol Chem 2008; 6: 2713-2718.

17. Kolak U, Topçu G, Birteksöz S, Ötük G, Ulubelen A. Terpenoids and steroids from the roots of Salvia blepharochlaena. Turk J Chem 2005; 29(2): 177-186.

18. Ododo MM, Choudhury MK, Dekebo AH. Structure elucidation of $\beta$-sitosterol with antibacterial activity from the root bark of Malva parviflora. SpringerPlus 2016; 5(1210): 1-11.

19. Nyemb JN, Ndoubalem R, Talla E, Tchinda AT, Ndjonka $D$, Henoumont $C$, Laurent S, Mbafor JT. DPPH antiradical scavenging, anthelmintic and phytochemical studies of Cissus poulnea roots. Asian Pac J Trop Med 2018; 11(4): 280-284.

20. Xie $Y H$, Deng $P$, Zhang $Y Q$, Yu WS. Studies on the chemical constituents from Cissus assamica. Zhong Yao Cai 2009; 32(2): 210-213.
21. Sani YM, Musa AM, Tajuddeen N, Abdullahi SM, Abdullahi MI, Pateh UU, Idris AY. Isoliquiritigenin andsitosterol from Cissus polyantha Tuber Glig and Brandt. J Med Plant Res 2015; 9(35): 918-921.

22. Kumar R, Patel DK, Prasad SK, Laloo D, Krishnamurthy $S$, Hemalatha $S$. Type 2 antidiabetic activity of bergenin from the roots of Caesalpinia digyna Rottler. Fitoterapia 2012; 83(2): 395-401.

23. Vishnu Prasad CN, Anjana $T$, Banerji $A$, Gopalakrishnapillai A. Gallic acid induces GLUT4 translocation and glucose uptake activity in 3T3-L1 cells. FEBS Lett 2010; 584(3): 531-536.

24. Kashima $Y$, Yamaki $H$, Suzuki T, Miyazawa M. Structureactivity relationships of bergenin derivatives effect on $\alpha$ glucosidase inhibition. J Enzyme Inhib Med Chem 2013; 28(6): 1162-1170.

25. Nkobole N, Houghton PJ, Hussein A, Lall N. Antidiabetic activity of Terminalia sericea constituents. Nat Prod Commun 2011; 6(11): 1585-1588. 